\title{
THE QUEST FOR THE SPIRITUAL SELF: ANTI-CAPITALIST AND NEO-LIBERAL FORMS OF SPIRITUALITY IN CONTEMPORARY ROMANIA
}

\author{
CRISTINE PALAGA 1
}

\begin{abstract}
In line with socio-anthropological theories meant to deconstruct the secularization teleology (Berger, 1997; Luckmann, 1967; Shah, 2015), this paper aims to document recent transformations in the field of Spirituality and Religion. Inheriting the analytical dichotomy between neo-liberal and anti-capitalist forms of spirituality, introduced by Carette and King (2005), I aim to emphasize both the common points and the ruptures between the subjectification technologies used within transformative self-development and self-help programmes, on the one hand, and a form of alternative Neo-Pagan spirituality, which opposes the capitalist way of organizing social, economic, political and cultural life, on the other hand. The rupture between anti-capitalist and neo-liberal forms of spirituality rests on identifying the extent to which the spiritual domain is colonized by an economically mundane ideology, in which the subject is invited to look upon spirituality as an internal resource meant to satisfy all the tropes of the neo-liberal economic imagery: optimization, efficiency, amplified productivity, abundance and prosperity. In addition to the ethnographic justification of this theoretical construct that supports the existence of two opposed poles of constituting a spiritual self, I will adjoin the cultural relationship between spirituality and capitalism to the wider problem of secularization, by arguing that spirituality is a byproduct of late modernity and a leitmotif of the power technologies through which the neoliberal subject is produced. ${ }^{2}$
\end{abstract}

Keywords: modernity, secularization teleology, personal/spiritual development, Neo-Paganism, (anti)capitalist forms of spirituality

\section{Introduction}

The societal secularization process (Dobbelaere, 2002) undermined the legitimizing authority of institutionalized religion, marking the failure of traditional theodicies, while generating new private and individualistic religious orientations.

${ }^{1}$ PhD Candidate in Sociology at Babeș-Bolyai University Cluj-Napoca, e-mail: palagacristine@gmail.com

2 This work was supported by a grant of the Romanian National Authority for Scientific Research and Innovation, CNCS - UEFISCDI, project number PN-II-RU-TE-2014-4-2515. 
Contrary to the secularization teleology, according to which modernity will undeniably exhaust a religiously transcendent view of the world, the social actor of late-modernity can create or subscribe to a personal and intimate form of spirituality by embracing disparate religious motifs, values or practices and bestowing meaning, habit and ritual onto them. Some of these emerging spiritualities contest the manner in which our lifestyle is shaped by the consumerist society, while others are permeated by market forces, becoming ingenious instruments that maintain and reproduce the capitalist ideology. In this paper I aim to investigate two opposing responses to religious individualization and privatization produced by societal secularization in contemporary Romania: first, Neo-Paganism ${ }^{3}$, a communitarian spiritual orientation, highly escapist, reactive and antagonistic to the capitalist way of organizing social, economic, political and cultural life and second, the so-called consumer-oriented private spiritualities/neo-liberal spiritualities (Carrette and King, 2005) - individualistic, socially disengaged and de-traditionalized forms of spirituality promoted by the spiritual/personal development programs and used by the neo-liberal agenda to create convenient individuals, that will voluntarily and uncritically embrace the status quo. Of course, there are various forms of spirituality that radically distance themselves from the consumerist, competitive and individualistic ethos promoted by and through the neo-liberal agenda. I selected Neo-paganism as the case study for capitalist counter-spirituality for the following reasons: first, I had already collected rich ethnographic data for my Bachelor's thesis on three Neo-Pagan movements in Romania: Wicca, Asatru and Zalmoxianism4. Beyond this personal preference originating in my conceptual familiarity and practical knowledge of Neo-Pagan spiritual orientations, the comparison between Neo-Paganism and neo-liberal spiritualities is justified by the similar sociodemographic background of their audience: mostly young to middle age individuals, with university degrees, well-paid jobs, that see themselves as members of the middle class. Both Neo-Paganism and neo-liberal spiritualities are private forms of religiosity, that shape themselves in contrast to institutionalized canonical religion. Moreover, they are both patchwork spiritualities (Wuthnow, 1998), promoting religious sensibilities that rest upon personal reinterpretation of religious themes and motifs. Last, but not least, they imply a new set of values, accompanied by a transformative process and concrete techniques of elevating the human being.

3 Neo-Paganism designates modern reconstructions of pre-Christian polytheistic religions (Strmiska, 2005).

4 Zalmoxianism is a contemporary replica of the religion of the Dacians, which are considered the ancestors of Romanians; they used to inhabit the areas around the Carpathians and the Lower Danube before the Roman conquest. 
Regarding the methodological aspects, I have decided to use "triangulation within the qualitative method" (Denzin, 1978), combining participant observation with in-depth semi-structured interviews and qualitative data analysis of both personal/spiritual development international books and popular Romanian blogs. The private and individual character of these spiritual movements has pushed me into a plural ethnographic adventure. Five years ago, I took part in a series of open-air rituals or ceremonies held in private residences or natural settings (for example Wiccan fertility ritual, or lighting the sacred fire with Zalmoxians). Regarding my first direct fieldwork experience on the topic of personal and spiritual development, I took part in an intensive two-day workshop during the autumn of 2016. The workshop aimed at providing participants with the proper instruments to obtain a state of 'inner congruence'. Being-incongruence describes a state of inner tranquillity, in which individuals can realign their feelings and actions by changing their inner selves.

In order to protect the identity of all the participants, who became subjects in my research endeavour, I anonymized all the data obtained through participatory observation and opportunistic interviews ${ }^{5}$. Up until now I have conducted fifteen in-depth semi-structured interviews with both consumers and personal/spiritual development service providers. I spoke to persons that perform trainings or attend courses and workshops on the following forms of spiritual/personal development: Yoga, Neo-Paganism, Access Bars techniques, the Silva Method, Bowen Therapy, Mindfulness, Familial Constellations and others. The interview questions mainly targeted aspects of neo-liberal spirituality (Carrette and King, 2005), trying to see if all the subjectification techniques used in these personal and spiritual developmental programmes promote a sense of individuality, amplifying one's spiritual self to the detriment of a collective/communitarian sort of spirituality. I also wanted to see if the interviewees were critical of the ways in which the mundane world is socially, politically, culturally and economically organized, or if they reinforced the mundane while pleading for small and relevant changes at a more personal/ individual level. Other interview questions explored the motivations behind adressing these personal/spiritual development programmes (workshops, books, courses, retreat camps) and the exact techniques and forces one needs to mobilize in order to obtain personal growth. Qualitative content analysis of the personal/spiritual development discourse, as comprised in international book production and successful Romanian on-line service platforms, also had a central position in my methodological strategy. This third method allowed

${ }^{5}$ An "opportunistic interview" (Costello, 2001) is an apparently informal discussion, with the subject of spiritual and personal development, without making explicit the research interest. 
me to adress both the amplitude and the mosaic character of the field. I mapped personal/spiritual development discourses from a vast array of fields, including: psychology, scientific medicine and alternative medicine, business and economical studies and, last but not least, from the field of alternative forms of spirituality.

The paper comprises two sections: in the first part of the article I will problematize the ways in which late modernity manifests itself in the field of religion, by tackling the ampler social processes that mark the transition from institutionalized dominant religions (dogmatic, cohesive and canonical) to private and individualized spiritualities, in which the social actor builds new symbolic universes according to his/her own worldview and his/her own expectations, and through which he/her is able to escape church-related religions. Another focal point of the investigation follows the ways in which the neo-liberal agenda finds breaches in these individualized spiritualities, breaches that can be easily colonized by market ideology. In the second section of the article I will be focusing on providing an ethnographic account of the emergence of Neo-Paganism and the neo-liberal spiritualities promoted by personal/spiritual development programmes in contemporary Romania. I will be discussing in a comparative manner the aesthetics, politics, systems of meaning and modes of belonging for these two different types of spirituality, that can be hijacked in order to sustain the neo-liberal order or seen as a way of constructing a new sacred cosmos, apart from modern exigencies.

\section{From institutionalized religion to private religiosity and consumer- oriented spirituality}

Imagining and anticipating the numerous ways in which modernity will reconfigure each and every region of human existence has a long intellectual tradition, representing both a favourite subject matter and a sybillinic attempt of predicting the future image of society for numerous scholars - Schopenhauer, Kant, Nietzsche, Spengler, Heidegger, Tönnies, Weber, Durkheim and so on. Their views were polarized, some of them trusting the beneficial impact of the modernization process, characterized by progress through Enlightenment, while others feared the negative effects - estrangement, alienation, loss of purpose and existential angst. Social scientists, regardless of their view on the positive or negative effects of the modernization process upon society and humankind, convene on the fact that modernity dislocates society from its "traditional" order, under the circumstances of industrialization, capitalization, rationalization and secularization (Giddens, 1991, emphasis added). 
Linked to the ontological region of religiosity, modernity is described as being secularized ${ }^{6}$ and "disenchanted" (Gog, 2007; Weber in Michel, 1997), i.e. completely petrified, mechanic and devoid of meaning (Saler, 2006; Seidman, 1983). The vast majority of authoritative socio-anthropological sources in the field of religion and secularization (Berger, Martin, Fenn, Parsons, Bellah in Tschannen, 1991; Wilson, 1981) assume that all references towards the supernatural, the sacred and the divine will dissipate at the conscious level of the social actor (Dobbelaere, 1981), as the modernization process comes to an end and as society achieves an increasingly complex and differentiated state (Durkheim, 1965). I think that we should not deny the reality of the secularization process, but we should also severely scrutinize the secularization teleology as religious individualist signification systems are empirically identifiable. At a societal level, secular value frameworks replace religious ones, but the individual is not invariably affected by the societal secularization process, continuing to be "religious" or "spiritual". The way in which religiosity and spirituality are conceptualized is deeply shaped by the secularization process, which produces a reactive antagonism with church-relatedreligions, privatization and individualization of the religious experience. We can therefore witness a transition of the sacred and transcendent from the public to the individual sphere, a byproduct of secularization and, at the same time, a source of de-secularization, away from institutionalization.

The "set in stone" authoritarian "meta-narratives" of institutionalized religions are replaced by ingenious individual forms of religiosity, in which the practitioner builds new symbolic universes according to his/her own worldview and his/her own expectations and through which he/she is able to escape churchrelated religions. The modern social actor can remain a religious subject while secularization permeates and expands on an organizational and societal level or, in other words, the same social world can be simultaneously secular and enchanted.

Modernity does not necessarily lead to a twilight of religion; on the contrary, it "simultaneously generates and destroys routine phenomena labelled as religious" (Gilsenan, 2000: 589). Therefore, it is time to question the taken-for-grantedness of this opposing relationship between religiosity as an exponent of the premodern and modern secularism. What I want to emphasize is that religiosity is not incompatible with the contemporary and, furthermore, religiosity, rebranded and commodified as "spirituality" becomes a subjectification tool, an ingenious instrument that can be used to maintain the neo-liberal status quo (Carrette

${ }^{6}$ We cannot talk about one singular coherent and integrating theory of secularization (Bruce, 2002; Gorski, 2000), but of a series of secularization paradigms, founded on a set of common concepts and assumptions like "differentiation", "rationalization" and "worldliness", "privatization" or "individualization". 
and King, 2005). Endless implicit or explicit invitations towards initiating a quest for the private self can be identified in the personal and spiritual development industry, which holds the promise of a mundane beneficial transformation using spiritual techniques such as meditation, bodily gestures (yoga), or more occult practices meant to attract abundance, wealth and prosperity.

Along with facilitating the permeation of religious motifs and practices into the capitalist worldview, the individuation of religious experience caused by the secularization process also allowed countercultural spiritual movements to emerge. Neo-Paganism is one such countercultural spiritual movement, that completely refuses the present state of society, smothered by consumerism, injustice and lack of meaning, proposing a "sacred cosmos", a better (old) new world in return. In the following section I will describe the main traits of neoliberal and anti-capitalist forms of spirituality while empirically exploring both the points of rupture and overlay areas between two different responses to the process of secularization, understood mainly as the process through which religion is no longer needed in order to legitimize the social life of the latemodernity actor, but a set of private and highly individualized spiritual beliefs and practices.

\section{Neo-liberal versus anti-capitalist forms of spirituality in contemporary Romania}

Starting from the conceptual rupture between neo-liberal and anticapitalist forms of spirituality, introduced by Carrette and King back in 2005, I contrast the subjectification techniques used in personal/spiritual development discourses on how the self should be governed and enhanced against those produced by Neo-Pagan forms of spirituality, which I consider as critical to the ways in which capitalism structures and organizes our social, political, economic and cultural life.

As a macroeconomic ideology, neo-liberalism promotes a marked-based economy, which needs to satisfy three fundamental criteria in order to be fully functional: reducing state involvement to the minimum, promoting efficiency and, last but not least, stimulating competition. According to the doctrine, the fulfilment of these criteria would undoubtedly lead to freedom, welfare and prosperity for all involved. Any problem or systemic irregularity that may occur is believed to be caused by insufficient liberalization and never by the system itself. This brief description of the neo-liberal economic doctrine is a perfect snapshot of the official discourse on reorganizing all aspects of social, economic or political institutions in postsocialist Romania, such as the public healthcare system, social services or the public education system. 
Capitalism was first adopted by institutions and afterwards infused into other sectors of social and cultural life. We are now witnessing the micro effects of the economic principles of neo-liberalism on the social actor who internalized the pillars of capitalist success: individuality, efficiency and competition. By identifying an ontological breach in the social actor's need for transcendental meaning, these three fundamental neo-liberal criteria and the promises of their fulfilment - wealth, progress, and social status - permeate into religiosity and produce changes in the self.

In the following section I will discuss neo-liberal and Neo-Pagan spiritualities in a comparative manner. The comparison is based on the following analytic categories: entry points; means of relating to the modern social world and the political attitude towards its systemic problems; religious imagery and promoted values. Last but not least, I will observe the transformative and ritual techniques that are specific to either of the two.

First I will elaborate on the subjects' entry points into personal or spiritual development literature and practical courses and into Neo-Paganism. All the persons interested in spiritual development entered the field in order to find answers to specific problems they were confronted with at a certain point in their lives. Some of them resorted to personal/spiritual development techniques to resolve health-related issues (those who appealed to Bowen therapy, for example). Others wanted to improve their social skills or professional capacities, while a smaller category hoped to find responses to deeper questions regarding the meaning of life or their purpose in the larger scheme of things. Acknowledging one's problems, doubled by the will to solve them marks the first step of the transformative process. Here is an intervention that I find highly illustrative of these facts:

(...) In my opinion, in life we all encounter the same problems - I mean... all adolescents have the same problems: they don't get along with their parents, they all rebel at some point. (...) It is hard to establish relationships with the persons around you, then you'll have a lover, then you'll go to college, then you'll have your first job, then you'll have your first marriage... and I think that personal development targest these generalities precisely, the problems we all have in common and then personal development gives us a hundred solutions for the same problems. And you can choose a solution for that problem, that one you consider more useful for yourself. And, thank God, we are all excessively good at creating problems! (X., female, 28, event planner).

At the beginning of the personal development workshop I attended, the trainer introduced several self-knowledge procedures, meant to make us acknowledge the problems that were keeping us from evolving. The problems, fears and anxieties that came through were numerous and diverse, but the most frequently mentioned ones were: the phobia of public speaking (which 
was considerably ameliorated until the end of this workshop), loneliness, the fear of not being loved and appreciated by the significant others in their lives, the inability to communicate freely with work colleagues, fear of loss, fear of stagnation. Some of the participants, who were familiar with the content and scenario of this kind of personal development workshops, said that they resolved their psychological blockages or social fears (partially or completely) and will continue to attend spiritual and personal development courses and workshops in order to get in touch with particular means and techniques through which they can enhance their qualities and capabilities. Some of the latter participants wanted specific know-hows on developing their sense of making profitable businesses, on influencing and manipulating others' decisions or on better addressing financial problems. Those subjects who "invested" a great amount of time, energy and financial resources into personal/spiritual development books, courses and workshops and came to view them with a critical lens, appreciate that the industry itself produces most of the problems it pretends to solve. Also, the industry of spiritual or personal development always addresses individual problems, never taking into account more general problems like access to health or education, environmental problems, or political crises. Mostly, the individual is the one blamed for the difficult situation he/she is dealing with.

All the interviews taken with Neo-Pagans showed that the disappointment caused by consumerism and the commodification of life itself, the downfall of the main pillars of the canonical cult and the interest shown to occultism, mythology and history paved the road towards the Neo-Pagan sacred cosmos:

\begin{abstract}
Me, I've always loved history. I think that in order to know who we are, we should study and understand what happened before we came. Of course, my opinion is against what the world wants us to believe nowadays. Everybody's focused on the present, on being competitive and planning for the future with money they don't have and probably never will. (...) I like to believe in a more romanticized world, a world in which we can talk about ancestry, real gods and traditions without appearing like a bunch of fools. (...) I became a Neo-Pagan because I refused to swallow lies from the authorities and the media and I went looking for this nostalgic deeper meaning. That's how I became a Zalmoxianist follower (Z., male, 28 years old, IT specialist).
\end{abstract}

Going further, I will circumscribe the religious imagery of Neo-Paganism and capitalist spiritualities. Capitalist spirituality tends to be eclectic and detraditionalized, although it takes the "aura of authenticity" of religious traditions for granted (Carrette and King, 2005:16). Both on a discursive and on a practical level, the spiritual attitude of the bloggers, trainers and book autors I have analysed proves to be sincretic, combining disparate religious themes and motifs. The individual who subscribes to these forms of spirituality chooses 
what they want to believe in, most often bringing together ideas and practices originating from two, three or more religions into a wholesome personal belief system. For example, within the same blog entry or throughout the works of the same author, one can notice both references to the spiritual advice provided by the Holy Fathers of Orthodox Christianity and concrete advice on how we can alleviate our karma of past sins, under the goal of reuniting with our Cosmic Self. Orthodox Christianity, oriental religious practices, clinical psychology and scientific medicine are no longer part of a distinct and irreconciliable discursive order. Each belief, regardless of its specific operating precepts opens a flux of cuantic potential by which everything falls into place according to one's own belief. Another relevant trait of neo-liberal forms of religiosity is the bestowing of spirituality upon any daily activity, regardless of how prosaic it may seem, in order to connect to the Divine Self.

Unlike capitalist forms of spirituality, anti-capitalist ones reclaim the authenticity given by millennial religious practices; the discourse on the authenticity and purity of their beliefs is of great relevance. I need to highlight that Neo-Paganism does not constitute a monolith spirituality. Instead, it is a conglomerate of numerous fractions, that encompass various ways to conceptualize religion starting from the animist doctrine, which claims that spirit is actively present in all objects, living beings and natural phenomena: "I believe that God is in everything: in that tree, within rocks, in you and in me. (...) He is everywhere, he doesn't sit on his cloud in the sky" (A., 26, male, chemist).

Some of the Neo-Pagan fractions - wiccans, for example - are both antitotalitarian and non-dogmatic (Gallagher, 1994), while others show a quasitolerant attitude towards other pagan denominations and no tolerance at all towards mainstream religion or other cults - as in the case of Zalmoxianism. While neo-liberal spiritualities advocate for the fusion of any religious elements, this is not the case for Neo-Paganism, in which the only allowed form of sincretism is the blending of pagan motifs, originating in polytheistic Celtic, Egyptian, Greek, Norse, Thracian, Roman or Slavs pre-Christian religions.

Pantheism is another common denominator between the two. In the case of neo-liberal spiritualities, although the Christian God is referenced directly on occasion, divinity is most frequently portrayed in a pantheistic manner. Despite the numerous variations of cosmologies and pantheons that characterize "new Paganism", a common feature is the belief in the existence of a "realm of gods, spirits and other beings perceived as part of a co-existing reality" (Greenwood, 2000:1). The Neo-Pagan gods are anthropomorphized, have names and specific features (Strmiska, 2005). When humanized, deities take both masculine and feminine forms and are seen as complementary halves of the same whole. The Neo-Pagan gods engage in extra-marital sexual relations, they develop pleasures and passions, sympathies and dislikes, they make mistakes and learn from them, just as the people they govern: 
(...) the limitations and imperfections of the gods they worship reflect the dynamics of life on Earth in a much more convincing manner than the absolute perfection of the supreme god worshipped by monotheistic religions (Strmiska, 2005:36).

To pagans, the divine has a double nature: both immanent (inside the human being - the individual becomes imbued by the divine in the case of rituals that lead to possession or inspiration) and external, transcendental: "Frigg [the Norse goddess of destiny and marriage] is the beauty of my mother's face and Odin guides me whatever I do, so I'm not afraid of anything anymore" (R, 26, female, assistant manager).

For both neo-liberal and Neo-Pagan spiritualities, the means through which new universes of significations are built is of rational, conscious nature as opposed to pre-modern religious realities which were not questioned, but instead internalized as they were. Within the frame of late modernity, the individual coerces himself or herself to an "act of faith" (Berger, 1967) in order to imagine a picture of the sacred. The deliberate is however transgressed along with the internalization of beliefs and practices; these are not invariably standardized. Instead, they are fluid and permissive, always open to renegotiation and redefinition.

As far as the promoted set of values is concerned, the Neo-Pagan moral edifice is built on the belief in the existence of an essential principle, much like karma - a principle of cosmic order and complementarity, a sublimed form of lex talionis, in which the universe balances and regulates the sum of relations between organisms and things. Love, simplicity, joy, happiness, pleasure, respect for nature and for one another lie at the foundation of the prescriptive infrastructure of modern pagan ethic (Bonewits, 2005). There are no such things as absolute good or evil: these principles are juxtaposed in a dialectic schema that generates cosmic unity. In the case of neo-liberal spiritualities, the virtues of the individual and, implicitly, the values one should work on acquiring are as follows: mastering different kinds of social and professional skills, being pragmatic and self-centred, above the influence of others, being strong, focused and determined, achieving economic success and prosperity by internalizing efficient and productive techniques of organizing one's life. The ultimate promise of pursuing these values is individual happiness itself. The problem is that the manners in which "happiness" is operationalized allows the exploitation of various schemes of social desirability regarding the individual's physical aspect, his or her health status, education, profession, income, intimate relations or social ties.

The following section will treat the different approaches towards modernity and contemporary social and political problems. Within the context of a radicalized and reflexive modernity, Neo-Pagans develop answers and strategies in a post- 
modern manner - "mistrust in meta-narratives", the decline of legitimizing narratives, syncretism and eclecticism, with "post" signifying "a restless and contesting relationship with the modern" (Michel, 1997:345), unlike those who embrace a neo-liberal spirituality, who take everything as it is, without questioning the fundaments or subtleties of their spiritual orientation.

From a Neo-Pagan perspective, modernity is the foulest and most destructive of all epochs:

\begin{abstract}
Modernity has stripped us of our most precious things: humanity, love. Today, everything is mercantile, reduced to making money and obtaining advantages (L., 27, salesman).

Modern life has uprooted us from our sacred traditions and sacred lands. (...) You see the same products everywhere, coming out of mass production facilities: milk tastes the same everywhere. Farmers are forced to sell out and submit to corporations. There is nothing sacred in this world anymore. Me, I can't willingly live in this world where nothing is holy. So, I went back to our ancient traditions, to the ways of our ancestors and I found something that this modern world can`t take from me anymore: pride and purpose! (Z., male, 28 years old, IT specialist and Zalmoxianist adept).
\end{abstract}

Another attitude often found among Neo-Pagans is that of rebuke, disapproval and downright hatred towards the implications of technological advancement in our everyday lives:

My grandparents, may they rest in peace, used to lead a simpler life and they were happier like that. They understood how things worked. (...) They communed with nature and had a certain simplicity in their lives (G., 24, female, waitress).

In Neo-Pagan circles, pantheism leads to the adoration of the metaphysical entity of nature, followed by a profoundly ecologist individual policy:

Man must understand, once and for all, that he is a part of nature and not its ruler. So long as we don't understand this thing, we'll witness more calamities and misfortunes, for nature cannot be suppressed. It is not like a horse you can tame. It has its own rule set and it's powerful, much more powerful than this cutting edge technology that humanity is developing (M., 19, male, student).

Neo-Pagans challenge the status quo, but only at a discursive level. Although they are sensible to all systemic problems, they don't want to programmatically face them or change the current state of things at a social level. All they want is to escape this reality and recreate a life based on simplicity, while being close to the gods and natural elements. Escapism also creates social insularities, in which Neo-Pagans recreate their life according to what they call "the natural way", away from technology, consumerism, workaholism and urban clusters. The Neo- 
Pagan replica to the modern way of life is an autonomous existence, in cohesion with nature, while gradually pulling away from the dominant socio-economic system. The first step in this quest of becoming in tune with the land is to establish a household away from urban centres, in areas that can provide the basic resources and raw materials needed to survive. The goal for most NeoPagans is to ultimately withdraw from the system as much as possible.

Neo-liberal spiritualities acknowledge the existence of social issues, but never point towards their societal roots. They propose a complete transfer of responsibility from society to the individual. Collective accountability is just an excuse for those who are unwilling "to be the change they want to see in the world". With no exception, all the books and blogs I have analysed promote this idea of "self-governance", by which only the individual is responsible for his/her wellbeing or his/her failure. Nothing in his/her social environment or anything related to the larger political or economic context can be blamed for the fragility or uncertainties one will encounter throughout their lifetime. This discourse is meant to de-focus the individuals from all the problems they cannot immediately control, such as hunger, poverty, gender inequality, or corruption. Another relevant trait of capitalist forms of spirituality is quetism, "a tacit acceptance of the inevitability of social injustice rather than a wish to overcome it" (Carrette and King, 2005:34). Unlike the personal and more immediate issues, the aforementioned larger problems are not within the individuals' reach and should not be the subject of his or her concern. It is assumed that only after resolving your intimate issues and anxieties can you hope to resolve systemic issues. The individual answerability trope is supported by an internal psychological and spiritual inalienable and ceaseless strength that we all invariably possess. The Self is an unlimited reservoir of strenght and stamina, able to fix any kind of problem or anxiety. The Self should not be understood as brute force that just needs to be channeled into the direction of problem solving, but as a evergrowing potential one can be taught to use.

This last comparative section follows the transformative processes and ritual frames proposed by both Neo-Pagan and neo-liberal types of spirituality.

Neo-liberal spiritualities claim that the transformative action of personal growth entails a long-term process: "The process of change must proceed throughout the course of the subject's entire life!" (F., 32, male, personal development trainer), although one needs to see small improvements in order to validate the usefulness of the personal/spiritual techniques. If the expected result is not achieved, no one other than the individual can be blamed. The sole person who applies the transformative techniques is responsible for the success or failure of the personal/spiritual development plan. There are many specialists in the field, but their knowledge cannot get one far if they will not 
consistently apply the principles they are advocating again and again. The coach, mentor, author or spiritual advisor is a simple mediator or coordinator in this quest of discovering and harvesting one's inner resources.

During the two-day intensive personal development training I have attended, we were constantly being told by the trainer that "There is no such thing as "I can't!". The trainer equated "I can't!" to the "I won't!" trope. If one can identify some weaknesses or some critical aspects in their life and they still do not spring into action to change them, lamenting that "it is impossible for them to change them", it means that they don't want to make the change because they are benefitting from their problems: "One has many advantages from being depressed or jobless, have you ever thought about that?", the trainer kept on provoking us. We were told we needed to stop lamenting and start disciplining our minds. Here the trainer made the first explicit connection to a religious tradition: 'We need Buddhism in our lives. We don't need therapy, but a setup, a mental discipline, "cause this is what Buddhism is really about". As far as I can tell, the trainer also used the concepts of "pain" and "suffering" in a Buddhist sense. We are the only ones responsible for all the pain and dissatisfaction we are experiencing, because pain becomes part of our lives when our world-model and our life expectancies are not congruent with the expectations we ourselves also create. Suffering intervenes when we feel powerless in changing that state of mind. The training concentrated on making us believe that we should stop controlling all the external aspects of our personal, professional and social lives and start concentrating on reprogramming our minds into creating a new, more balanced mindset. One should not blame the external context for all the unjust of unpleasant situations encountered throughout one's lifetime. This complete responsabilization of the individual is strongly associated with neo-liberal political discourses, in the context of which it takes on the implication that the subject being now responsibilized has avoided his/her duties or taking responsibility for their acts, always blaming other persons, forces or the larger context for their failings or problems.

Each trainer, each personal or spiritual development programme proposes some instruments, some specific techniques one should use in order to acces his or her own subjectivity. The use of "psycho-physical techniques that seek to pacify feelings of anxiety and disquiet at the individual level rather than seeking to challenge the social, political and economic inequalities that cause such distress" are labelled as thought-control mechanisms (Carrette and King, 2005:34, emphasis added). Here are some techniques, practices and mental adjustments the individual can instrument in order to access his or her own subjectivity, as proposed by the persons I have interviewed: different forms of inner energy, which can be harvested and channelled through bodily gestures 
or postured (Yoga, Access bard, Emotional Freedom Technique); taming one's (conscious) mind through neuro-linguistic programming; learning how to elaborate specific objectives and identifying the most useful way to reach them; meditation as a way to connect with one's "true", "authentic" self.

I now want to insist on the extent of the conceptualization of one's inner strenght and capabilities, as presented in the blogs I have analysed. In this scheme, the individual is literally the creator of their own destiny and reality. Using his/her cognitive force, the individual is able to chanel some energetic fluxes that become manifest in the external world as well: "The material world and the unseen one are the result of the intersection of worlds created by the minds of all the beings in that space". ${ }^{7}$ This is the reason why it becomes very important to not concentrate on the thoughts that betray negativity, fear or uncertainty, because all these feelings will be projected into our external lives. By controlling our minds and the great turmoil of thoughts, we can consciously create a reality in which we can know happiness. In order to control the flux of negative thoughts we can resort to mantras, constantly repeating phrases such as: "I am important, I am of great value, I can do anything I tell myself to do, I am intelligent, I expect only great things from myself; there is no obstacle I can't overcome (...)" or "I am the eternal manifestation of Self-respect; I am the eternal manifestation of Self-acceptance; I am the eternal manifestation of Self-appreciation"8.

During the workshop we were also constantly being told by the trainer that we are our own biggest enemies and the only way one can obtain the state of 'congruence' (a state of inner tranquillity, in which individuals can realign their feelings and actions by changing their inner selves) is by mastering his or her mind. One should start taming the mind by bringing himself or herself into the present. Only by acknowledging the present mental, emotional, physical state can we identify the most efficient strategy to be used in order to obtain the desired state. The mind is a complex apparatus, but it doesn't differentiate between reality and fiction; the mind does exactly what we program it to do. The good part is that we can learn how to program our minds in order to do anything: from instant healing to attracting wealth and prosperity and the right people in our lives. The lesser part is that we are continuously sabotaged by our subconscious self, a part of us that is not currently in focal awareness. We can silence the effect of our subconscious through some specific techniques.

\footnotetext{
${ }^{7}$ Source: http://www.holisterapi.ro/holistic/sfaturi-utile/\#sthash.zfUlkzzB.dpuf [last accessed: 15.08.2016]

8 Source: http://www.holisterapi.ro/holistic/terapie-holistica/regasirea-puterii-interioareholistic/page/2/

[last accessed: 15.08.2016]
} 
The first and most effective measurement we can take against the 'enemy' is to create a healthy and stable mental map in the conscious by training a new voice that constantly gives short and clear orders to the mind. But first, one needs to identify the object of her or his desire, a certain objective, that needs to be 'SMART'- specific, measurable, assignable, realistic and time-related. "We need to be more specific with ourselves, otherwise the mind will not be able to process our desires and needs", the trainer said repeatedly. Also, the way in which we address our mind is vital; we need to renounce negative terms and modal verbs. When we address the mind, we shouldn't say: "I would like to be paid one hundred euros more each and every month", but "I will be paid one hundred euros more each and every month, starting from...". Also, we need to stop comparing ourselves to others: the only validation we need comes from within. The process of obtaining what we want, even though we are talking about a psychological quality like patience or serenity or something more 'material', like money or a lover does not need a severe control of the conditions of possibility, because "everything is possible" once we really want it and tell our mind to go get it. We need to live as if we already possess the object of our desire or like we have already reached our objective: "We need to be there, in the moment of success. We need to be able to smell, to see, hear and to touch success" (F., 32, male, personal development trainer). Before giving a command to our minds, we need to be certain of the utility of what we are asking from it. So, we need to be attentive to the 'ecology' of our thoughts, to anticipate all the advantages and the disadvantages of reaching our objectives.

Similar to neo-liberal forms of spirituality, Neo-Pagans have the conviction that human minds are able to create and perform religious and magical rituals, given the proper training and discipline (Bonewits, 2005). As a ritual common denominator, Neo-Pagans bestow great importance onto the solemn celebration of solar and lunar cycles through so-called "intensification rites" (rituals performed upon solstices and equinoxes) and "rites of passage" (the ritual celebration of reaching certain milestones in life). The ritual array creates an ingenious buffer zone against rationalism and ceremonial practices converge towards a form of communication with the outer world of gods. For Neo-Pagans, "souls and supernatural beings and forces are real" (Wallace, 1966:52). Neo-Pagans organize their ritual calendar according to the "yearly wheel" - the solar seasonal cycle, and their ritual practices vary between individual rites and collective ceremonies (Jorgensen and Russel, 1999). These rituals often take place in open spaces (forests, groves, river banks) because "that's how we can get closer to the Gods" (A1, 21, female, student). Some Neo-Pagans own personal altars, at which they meditate, pray, perform ritual songs, incantations and provide offerings to their governing gods. Each Neo-Pagan tradition employs divination practices: tarot or runes. Prayers are also paramount in Neo-Paganism: 
I pray to the Goddess, she always takes care of me and S. and our little girl and she caters to our every need. When I have a problem with my wife or at work, or if I'm simply feeling down, she always comes to my aid. (...) It's enough to light a candle, call her, while intensely focusing on my problem, and she enlightens me - then I know what to do to make things better (C., 32 , male).

I'd rather dedicate lyrics to female goddesses. Without them, life would be bland; they are the beauty of the world, the blue sky and life's great mystery $(\mathrm{V}, 22$, female, "poet and composer").

The Neo-Pagan religious imaginary attests to the recurrence of spirituality in the modern world, as new forms of transcendence become increasingly more visible within the social life, away from the logic of personal enhancement for success and profit. The emergence of Neo-Pagan counterculture illustrates a process of rejuvenating the sacred through reinventing the value of ancient spiritual mysteries and religious rituals.

\section{Conclusions}

There is a tight relationship between the decline of institutional religion and the emergence of such forms as private spiritualities. Religious pluralism, as well as the privatization and individualization of religious sensibilities allowed the ascent of consumerist and capitalist forms of spirituality, which entail the use of religious motifs in order to cope with the rigors and pressures generated by the modern quest for personal and professional identity (De Lange, 2011). In this scheme, spirituality becomes both "a cure for the isolation created by a materialistic, competitive and individualized social system" (Carrette and King, 2005:40) and a mechanism that pleads for "self-governance", promoting the idea that the individual is an infinite reservoir of potential and agency, having the capacity to change any context in order to better suit his or her interest. The subordination and exploitation of religious themes to promote the individualist and corporate-oriented pursuit of profit (Carette and King, 2005) constitutes the main trait of capitalist spiritualities. The same secularization process can also create bubbles of meaning through which one can (partially or completely) evade the neo-liberal techniques of subjectification, imagining a new enchanted world.

A common trait found in the principles of most neo-liberal spiritualities is the concept of pure individual development, with little to no reference ever being made to the inequities of the world and the socio-political context of the present. The individual is moulded towards becoming a self-sufficient agent, the sole bearer of responsibility for the outcomes of his or her actions. The 
over-arching neo-liberal system, with its social, political and economic dimensions, is portrayed as the only possible canvas on which the social actor can plot a route towards either success or failure. Whether the end result is the former or the latter, that is purely up to each single one of us. The outside world is but a mirror image of our mentality and our interior universe. However, the responsibility for failure is further emphasized by the fact that we are all supposedly given the necessary tools to succeed. This being said, it is important to note that all self-development programmes and neo-liberal spiritualities promote individual resilience and a "never give up" attitude, repeatedly stating that failure is one of the most important steps towards reaching one's goals. Individuals are taught to learn from failure and be driven by it because the capitalist system requires relentlessly active social actors to keep it running. A person who experiences ultimate failure is no longer a productive member of society. Their potential productivity is not only lost, but they become a burden on the entire community.

On the other hand, by returning to old belief systems, Neo-Pagans seek to craft an alternative to modernity, which they view as one of the two main causes that lead to a "corrupted world", the other being Christianity. Neo-Pagans reject the frameworks of modernity, capitalism and organized religion, leading their life based on the common core pillars of ancient beliefs: communion with nature and the spiritual realm, observing behavioural standards such as honour, honesty and integrity. The ultimate goal for many Neo-Pagan followers is to withdraw from the neo-liberal system and achieve a state of self-sufficiency outside the constraints of modern society and politics. Even though Neo-Pagans can be found working in corporate environments alongside individuals who regularly attend self-development courses, their goals lie in direct opposition. While the latter category seeks success within the system, the former sees the corporate lifestyle as a necessary evil that will eventually allow them to amass the capital for self-funded methods of escapism. To conclude, the self-sufficiency sought by Neo-Pagans lies outside the boundaries of the system. A self-funded life, with little or no interaction with the mainstream is their overall goal, whereas neo-liberal self-sufficiency is aimed towards creating an individual who sees no faults within the system, but rather looks ever inwards for the solutions to his or her problems.

The modern individual uses spirituality in order to create new symbolic instances and interpretations that are able to provide legitimacy to the order of everyday mundane life or to denounce it as being foul, proposing a new sacred cosmos instead. Within the spirit of post-modern reactive antagonism with church-related-religions, the emergence of new forms of spirituality and new religious movements attests a phenomenon of "re-enchantment of the world", 
constituting a new vein for the critical investigation regarding a unique and irreversible secularization process, while also giving us the chance to critically investigate the ways in which spirituality is used by the neo-liberal agenda in order to create 'convenient' subjects. The need for sense and significance, doubled by the pressure of constantly inventing ourselves (De Lange, 2011) and the necessity of coping with all the anxieties created by the modern way of life constitute breaches that can be easily overturned by the corporate environment, which uses spirituality to create and celebrate forms of autonomy and selfrealization. Spirituality has a key role in constructing "governable subjects" (Rose, 1999), our personal subjectivity becoming a very useful instrument of control and domination. The focus now lays on the individual self, holder of unlimited potential and, in itself, owner of every mechanism through which personal or professional life can be organized in a desirable manner. The pressure of the gruelling project of building a resource-self, that holds the energy, vigour and internal capacities which can be orchestrated towards excelling in everyday life, cannot be removed from the frame given by the capitalist ethos. Self-governance is a very ingenious method of disciplining and controlling the subject, who grows to internalize and implicitly naturalize the key principles of neo-liberal government. The abundance of self-development programmes, personal, spiritual and entrepreneurial growth is an expression of the means through which the individual attempts to solve the issue of an identity that is in a constant state of crisis.

\section{REFERENCES}

Berger, P. (1967). The sacred canopy: Elements of a sociological theory of religion. New York: Anchor Books.

Bruce, S. (2002). God is dead: Secularization in the West. Oxford: Blackwell.

Bonewits, I. (2005). What Neo-pagans Believe or Neo-pagan Polytheology 101. [online] Available at: http://www.neopagan.net/NeopagansBelieve.html [Accessed 01.07.2017].

Carrette, J., King, R. (2005). Selling Spirituality. The Silent Takeover of Religion. New York: Routledge.

Costello, J. (2001). Nursing older dying patients: findings from an ethnographic study of death and dying in elderly care wards. Journal of Advanced Nursing, 35(1):5968. 
THE QUEST FOR THE SPIRITUAL SELF: ANTI-CAPITALIST AND NEO-LIBERAL FORMS OF SPIRITUALITY ...

De Lange, F. (2011). Inventing yourself: How Older Adults Deal with the Pressure of Late-Modern Identity Construction. In Kenyon, G., Bohlmeijer, E., Randall, W.L. (eds.). Storying Later Life. Issues, Investigations, and Interventions in Narrative Gerontology. New York: Oxford University Press, pp. 51-66.

Denzin, N. K. (1978). The Research Act: A Theoretical Introduction to Sociological Methods. New York: McGraw-Hill

Dobbelaere, K. (1981). Secularization: A Multi-Dimensional Concept Current Sociology, 29(2).

Dobbelaere, K. (2002). Secularization: An analysis at three levels. Brussels: Peter Lang.

Durkheim, E. (1965). The Elementary Forms of the Religious Life. New York: The Free Press.

Gallagher, E. (1994). A Religion without Converts? Becoming a Neo-Pagan. Journal of the American Academy of Religion, 62(3):851-867.

Giddens, A. (1991). The Consequences of Modernity. Stanford: Stanford University Press, pp. 1-53.

Gilsenan, M. (2000). Signs of Truth: Enchantment, Modernity and the Dreams of Peasent Women. The Journal of the Royal Anthropological Institute, 6(4):597-615.

Gog, S. (2007). Raționalizarea sferelor de valori și problema dezvrăjirii lumii la Max Weber. [The Rationalization of Value Spheres and The Disenchantment of the World in Max Weber's Work]. ORMA. Revistă de studii etnologice și istorice-religioase [ORMA. Magazine for Ethnological, historical and religious studies], 6:26:54.

Gorski, P. S. (2000). Historicizing the Secularization Debate: Church, State and Society in Late Medieval and Early Modern Europe, ca. 1300 to 1700. American Sociological Review, 65(1), 138-167.

Greenwood, S. (2000). Magic, Witchcraft and the Otherworld. An Anthropology. Oxford: Berg.

Jorgensen, D.L. \& Russel, S.E. (1999). American Neopaganism: The Participants' Social Identities. Journal for the Scientific Study of Religion, 38(3):325-338.

Luckmann, T. (1967). The Invisible Religion, New York: Macmillan.

Rose, N. (1999). Governing the Soul: The Shaping of the Private Self. London: Free Association Books.

Michel, A. (1997). Differentiation vs. Disenchantment: The Persistence of Modernity from Max Weber to Jean-François Lyotard. German Studies Review, 20(3):343-370.

Saler, M. (2006). Modernity and Enchantment: A Historiographic Review. The American History Review, 111(3): 692-716.

Seidman, S. (1983). Modernity, Meaning and Cultural Pessimism in Max Weber. Sociological Analysis, 44(4):267-278.

Shah, T. S. (2015). Secular Militancy as an Obstacle to Peacebuilding. In Omer, A. (ed.). The Oxford Handbook of Religion, Conflict, and Peacebuilding. New York: Oxford University Press, pp. 380-407.

Strmiska, M.F. (2005). Modern Paganism in World Cultures. Comparative Perspectives. Santa Barbara: ABC Clio.

Tschannen, O. (1991). The Secularization Paradigm. A Systematization. Journal for the Scientific Study of Religion, 30(4):395-415.

Wallace, A. (1966). Religion. An Anthropological View. New York: Random House. 
CRISTINE PALAGA

Wilson, B. (1981). Religion in Sociological Perspective. Oxford: Oxford University Press.

Wuthnow, T. (1998). After Heaven: Spirituality in America Since the 1950s. Berkeley: University of California Press. 